IZA DP No. 7254

The Labor Market Behavior of Married Women with Young Children in the U.S.:

Have Differences by Religion Disappeared?

Evelyn L. Lehrer

Yu Chen

February 2013 


\title{
The Labor Market Behavior of Married Women with Young Children in the U.S.: Have Differences by Religion Disappeared?
}

\author{
Evelyn L. Lehrer \\ University of Illinois at Chicago \\ and IZA \\ Yu Chen \\ University of Illinois at Chicago
}

Discussion Paper No. 7254

February 2013

IZA

P.O. Box 7240

53072 Bonn

Germany

\author{
Phone: +49-228-3894-0 \\ Fax: +49-228-3894-180 \\ E-mail: iza@iza.org
}

\begin{abstract}
Any opinions expressed here are those of the author(s) and not those of IZA. Research published in this series may include views on policy, but the institute itself takes no institutional policy positions. The IZA research network is committed to the IZA Guiding Principles of Research Integrity.

The Institute for the Study of Labor (IZA) in Bonn is a local and virtual international research center and a place of communication between science, politics and business. IZA is an independent nonprofit organization supported by Deutsche Post Foundation. The center is associated with the University of Bonn and offers a stimulating research environment through its international network, workshops and conferences, data service, project support, research visits and doctoral program. IZA engages in (i) original and internationally competitive research in all fields of labor economics, (ii) development of policy concepts, and (iii) dissemination of research results and concepts to the interested public.
\end{abstract}

IZA Discussion Papers often represent preliminary work and are circulated to encourage discussion. Citation of such a paper should account for its provisional character. A revised version may be available directly from the author. 
IZA Discussion Paper No. 7254

February 2013

\begin{abstract}
The Labor Market Behavior of Married Women with Young Children in the U.S.: Have Differences by Religion Disappeared?*

Using data from the 2006-2010 National Survey of Family Growth, conducted in the United States, we study the role of religious affiliation and participation in the labor supply behavior of non-Hispanic married women with young children. We estimate ordered probit models with a trichotomous dependent variable indicating full-time employment, part-time employment or non-employment. We find that the labor market decisions of Catholic women are not significantly different from those of their mainline Protestant counterparts, and that women affiliated with conservative Protestant denominations continue to stand out for their low levels of labor market attachment. With regard to religious participation, we find a non-linear association: the probability of non-employment is high both among women who have zero attendance at religious services and among those who attend more than once a week - the latter especially. Reasons for these non-linearities are explored. Our results suggest that future research on relationships between religious participation and various economic and demographic outcomes should be based on models that allow for non-linearities and also for differences in the effects of religious participation by religious affiliation.
\end{abstract}

JEL Classification: J22, J24, Z12, Z13

Keywords: $\quad$ women's labor market behavior, female employment, religion, religious affiliation, religious participation

Corresponding author:

Evelyn L. Lehrer

University of Illinois at Chicago

Department of Economics (m/c 144)

601 South Morgan Street

Chicago, IL 60607-7121

USA

E-mail: elehrer@uic.edu

\footnotetext{
* We gratefully acknowledge helpful comments from Sedefka Beck, Houston Stokes, an anonymous referee, and participants at the Conference on Religion and Inequality, Duke University, September 14, 2012.
} 
The Labor Market Behavior of Married Women with Young Children in the U.S.: Have Differences by Religion Disappeared?

\section{INTRODUCTION}

Much of what is known about the role of religion in women's labor market behavior on the U.S. is based on studies that are now dated. Analyses of the 1987-88 National Survey of Families and Households (NSFH) found relatively low levels of employment among nonHispanic white conservative Protestant wives with children under age 6 (Lehrer 1995). Using data from the Youth Parent Socialization Panel Study (1965, 1973, 1982), Sherkat (2000) found an association between belief in Bible inerrancy and young women's decisions to be housewives early in the life course. And based on data from the 1987/1988-1993 NSFH, Glass \& Nath (2006) found that affiliation with a conservative denomination was associated with a decrease in white women's labor supply after marriage and after a marital birth. More recently, Putnam \& Campbell (2010, Chapter 8) noted that although a narrow gap persists, egalitarian gender norms have been largely accepted by both secular and religious women in the U.S., including those affiliated with conservative Protestant religions - and that at present differences in women's labor force participation rates by religious affiliation and participation are very small. These conclusions were based on descriptive statistics for a pooled sample of all female respondents in the 2008 General Social Survey.

In this paper we take advantage of newly released data from the 2006-2010 National Survey of Family Growth (NSFG) to study more closely the role of religion in women's time allocation decisions. Earlier research has shown significant differences across racial/ ethnic groups in how various factors influence women's labor supply (Lehrer 1992; England et al. 2004), in various aspects of religious belief and practice (Ellison \& Sherkat 1995; Ellison \& Hummer 2010), and in the relationships between religion and economic/ demographic variables Lehrer 2006; Fitzgerald \& Glass 2008) - suggesting the importance of conducting separate analyses by race/ethnicity. Due to limitations of sample size, in this study we analyze data on non-Hispanic whites only. In addition, we focus on women with young children, the sub-group 
for which theory suggests that affiliation with conservative Protestant denominations may matter. As Sherkat (2000, p. 347) noted - commenting on the works of conservative Christian writers they "are not loath to women in the workforce, but instead are articulating opposition to mothers of young children in the workforce.” We further restrict the analysis to mothers who are married, as their single counterparts have limited degrees of freedom in their labor supply choices. We consider a trichotomous measure of labor supply- full-time employment (FT), part-time employment (PT), and non-employment (NE), and two dimensions of religion - religious affiliation and frequency of attendance at religious services.

Why should religious affiliation be expected to influence female time allocation decisions? Building on earlier theoretical analyses, we make a distinction between direct and indirect effects (Keister 2005, 2011; Lehrer 2004, 2009). Those religions that emphasize the traditional intra-family division of labor - with clearly delineated separate roles for men and women - give psychic rewards to women who allocate their time primarily to their young children. This has a direct impact on the cost/benefit calculations of whether or not to work in the labor market and if so, how much. As to the indirect influence, religion has an impact on the perceived benefits and costs of choices regarding education, cohabitation, marriage, divorce, fertility, and the formation of religion-based social networks, among other socio-economic and demographic variables - and decisions made in these various realms over the life cycle have an effect in turn on subsequent decisions and outcomes related to work in the labor market.

For the group we study - non-Hispanic whites - the four main religious categories in the U.S. are conservative Protestants (CP), mainline Protestants (MP), Catholics, and the unaffiliated. There is evidence that in many outcomes, including education, fertility, divorce and wealth, non-Hispanic Catholics in the U.S. have converged to the MP pattern (Jones \& Westoff 1979; Lehrer 1999a; Lehrer \& Chiswick 1993; Keister 2003, 2007, 2011). Previous research suggests that there has been a convergence also in gender ideologies (Brinkerhoff \& MacKie 1988) and women's labor market behavior (Lehrer 1995). ${ }^{1}$ We thus hypothesize that our analysis will uncover no significant differences between Catholics and MPs on these fronts.

In marked contrast, CPs have remained distinctive in many economic and demographic behaviors, reflecting in part a low degree of complementarity or even anti-complementarity 
between investments in religious and secular human capital (Chiswick 2006; 2010). CPs have been found to have a relatively low level of educational attainment (Darnell \& Sherkat 1997; Sherkat \& Darnell 1999; Lehrer 1999a; Sherkat 2012), comparatively high fertility (Hout et al. 2001) and out-of- wedlock childbearing (Pearce 2010), and early entry into marriage and parenthood (Fitzgerald \& Glass 2008, Uecker \& Stokes 2009) - with these choices leading CP women to a path of comparatively low wages and labor market achievements (Lehrer 2010; Fitzgerald \& Glass 2012). Patterns of assortative mating in the marriage market imply that CP women tend to be married with CP men, who also attain relatively low levels of schooling (Massengill 2008). All of these factors combine to place CP families at the low end of the spectrum in the distribution of wealth (Keister 2008, 2010). Affiliation with a CP denomination is expected to influence women's labor supply behavior indirectly via all these paths. The direction of the net indirect effect is ambiguous a priori and its size may be small, because of offsetting effects (e.g., while the relatively low education level and opportunity cost of time of $\mathrm{CP}$ women leads to lower levels of female employment, the relatively low education and permanent income of their husbands operates in the opposite direction). The direct effect of affiliation with a CP denomination is clearer: although there is heterogeneity within CP groups with regard to norms on the appropriate intra-family division of labor, CP denominations have tended to be supportive of gender ideologies that emphasize different roles for men and women (Bartkowski \& Xu 2010). Evidence from earlier periods suggests that this direct influence has been important (Lehrer 1995; Sherkat 2000; Glass \& Nath 2006). Gallagher \& Smith (1999) have noted that considerations related to the inability of many families to subsist on one paycheck have led to pragmatic revisions of traditional ideologies. A question that we examine in this paper is whether or not white, non-Hispanic CP mothers of young children hold such ideologies at present and if so, whether they are associated with decreased levels of work in the labor market.

Religious nones constitute a growing and highly heterogeneous group, which includes agnostics, atheists, and people who describe themselves as "nothing in particular" (Massengill \& MacGregor 2012); some are individuals in search for a new religious home (Roof 1999). Using data from the 1998-2000 General Social Surveys, Hout \& Fischer (2002) found that, contrary to common perception, $68 \%$ of non-affiliated respondents indicated belief in God or a higher 
power. They also found that much of the increase in the ranks of the unaffiliated during the 1990s reflected a move to individualized, non-institutional forms of religion by political moderates and liberals - a result they interpret as a negative reaction to the Religious Right. The unaffiliated have received little attention in previous analyses of the connection between religion and women's employment. An exception is work by Glass \& Jacobs (2005); they find that, other factors held constant, white women raised with no religious affiliation have relatively low levels of participation in the labor market.

On theoretical grounds, the direction of the indirect effect of having no affliliation is unclear a priori, in part because research to date has reported mixed findings on the socioeconomic and demographic characteristics of religious nones. While some studies have found that individuals raised with no religion attain comparatively low levels of education (Glass \& Jacobs 2005; Fitzgerald \& Glass 2008), others have found that the non-affiliated are disproportionately represented among college professors and scientists (Ecklund \& Scheitle 2007; Gross \& Simmons 2009). These seemingly conflicting results reflect the many different reasons that lead people to self-describe as having no religious affiliation, as well as changes over time in the composition of the unaffiliated group and in the relationship between nonaffiliation and education (Massengill \& MacGregor 2012). There is less ambiguity with regard to the direct effect of non-affiliation: unaffiliated women are known to hold non-traditional attitudes (Sweet \& Bumpass 1990; Vella 1994), and in particular are likely to adhere to egalitarian gender ideologies that see little incompatibility between maternal employment and raising young children.

The other dimension of religion considered in this study is attendance at religious services. For some individuals, such attendance is zero because they are among the religious nones discussed above - the subset within that group that has chosen to have no connection to organized religion in their lives. For others, attendance is zero because they are lapsed MPs, CPs or Catholics - individuals who have retained their respective affiliations only nominally. Among those who do participate in religious services, frequency of attendance generally varies with the level of commitment to the faith. 
Religious participation may influence female time allocation decisions through two main pathways. First, some involvement in religious activities has been linked to better physical and mental health (Ellison \& Hummer 2010), higher educational attainment and income (Gruber 2005), less problems of substance use (Gruber \& Hungerman 2008), and higher levels of happiness (Cohen-Zada \& Sander 2009), among many other beneficial outcomes. ${ }^{2}$ Recent research has suggested the possibility of non-linearities, with these positive outcomes driven by some, but not extremely high, levels of religious involvement (Chiswick \& Huang 2008; Lehrer et al. 2009; Lehrer 2011). ${ }^{3}$ Although the benefits of some involvement with religion likely extend to the area of women's work in the labor market, the direction of this effect is unclear a priori. Having better health, being more educated, happier, and not addicted to drugs are all unambiguously "good” outcomes. There is no such clarity when it comes to maternal employment. While for some the "beneficial outcome” of involvement in religious activity may be greater ability to handle the simultaneous challenges of motherhood and employment, for others it may take the form of greater ability to manage with only one paycheck so as to permit increased investments of maternal time in young children. If the former relationship is dominant, the "benefits from some religious participation effect" would imply that non-participation in religious activities is conducive to non participation in the labor force.

The second pathway is more straightforward: a higher level of religiosity is expected to accentuate the effects of religious affiliation. Since most religions in the U.S. have messages that make home and family a high priority, those women who attend religious services more frequently - and are likely more influenced by such messages - are expected to display relatively low levels of work in the labor market when a young child is present in the household. Attendance at services also implies social connections with like-minded individuals, and the influence of peers could help reinforce the perceived benefits for women of staying home with their young children. This second pathway suggests the importance of considering religious affiliation and participation jointly, since it is CP denominations that most stress that women with young children should give high priority to home and family. 


\section{METHODS}

Data

The 2006-2010 NSFG questionnaires were conducted by the National Center for Health Statistics. They were addressed to nationally representative samples of men and women ages 1544 of all marital statuses living in the United States. The present study uses the female survey ( $\mathrm{N}$ $=12,279)$. We restricted the sample in several ways: to non-Hispanic white women $(\mathrm{N}=6,301)$, who were currently married $(\mathrm{N}=2,357)$, with a child under six living in the household $(\mathrm{N}=$ $1,005)$, with current religious affiliation in one of the main four categories $(\mathrm{N}=863)$, nonmissing information on attendance at religious services $(\mathrm{N}=862)$, not enrolled in school $(\mathrm{N}=$ 804), and not currently unemployed ( $\mathrm{N}=783)$.

\section{Measures}

The dependent variable is trichotomous, indicating the respondent's employment status during the week prior to the interview. It equals 1, 2 or 3 if she reported FT employment, PT employment, or NE, respectively. The percentages corresponding to these three categories are $38 \%$, $28 \%$, and $34 \%$.

With regard to the explanatory variable of central interest, religion, we consider the respondent's current religious affiliation, based on Steensland et al.’s (2000) classification scheme, ${ }^{4}$ and her current frequency of attendance at religious services (Table 1, Panel A). ${ }^{5}$ We also consider the two variables jointly (Table 1, Panel B), and a composite variable similar to that used by Keister (2008) which combines the affiliation in which the respondent was raised and her current affiliation (Table 1 , Panel C). ${ }^{6}$

Table 2 shows definitions and means for the economic and demographic variables included in the labor supply models. Two important determinants of women's time allocation decisions are her wage rate and previous labor market experience. Given the endogeneity of these variables and lack of adequate instruments, we estimate reduced-form equations which include instead their exogenous determinants: the woman's education (a proxy for the value of her time), her age and age squared, and the number of children in the household - an indicator of 
possible previous interruptions of full-time labor market activity. The children variable also indicates in part the current productivity of maternal time spent at home. Dummy variables for the presence of a child from an earlier union of the wife or husband allow for the possibility that women's employment decisions may vary depending on whether or not a child in the household represents human capital specific to a different union - such children may receive a lower level of investment of the mother's/ stepmother's time. The husband's education is included as a proxy for his permanent income, another factor that can play an important role in women's employment decisions. Finally, a dummy variable for the spouses belonging to different racial/ ethnic groups is included to allow for the possibility that heterogamy in this regard may lead women to work more in the labor market as insurance against the dissolution of their union. ${ }^{7}$

Table 3 reports means of variables that capture two dimensions of gender ideology: the concepts that the spheres of life meriting priority should be different for men and women, and that the mother-child relationship quality is adversely affected by maternal employment. They are based, respectively, on the following statements: (a) "It is much better for everyone if the man earns the main living and the woman takes care of the home and family," and (b) “A working mother can establish just as warm and secure a relationship with her children as a mother who does not work.” Responses to each item range from strongly agree (1) to strongly disagree (5); the first was reverse coded so that a higher number indicates a more traditional attitude in both cases. The descriptive statistics in Table 3 show that for both gender ideology measures, CP women stand out for being more traditional than their non-CP counterparts, and those with very high or high frequency of attendance at religious services hold more traditional attitudes than those who never attend services.

\section{Models}

We estimate three ordered probit models for each of our measures of religion. The first is a zero-order regression, with religion variables only; the second adds the economic and demographic variables; and the third adds the two gender ideology variables. With all these variables included, any remaining influence of religion would be attributable to socio-economic/ demographic factors not measured in these data and aspects of gender ideologies not captured by our separate spheres and relationship quality measures. ${ }^{8}$ 
A limitation of our analysis is that it is based on a cross-sectional data set, and moreover one where religious attendance was measured as of the survey date - the same point in time at which female employment was measured. Because of the contemporaneous nature of the religious participation and employment variables, the estimates presented below must be viewed as descriptive only - aiming to measure associations rather than causal effects. Our data set does contain variables for religious affiliation measured both at the time of the interview and during childhood, and we use the latter information to help address concerns of reciprocal causality.

\section{RESULTS}

\section{Current Religious Affiliation}

Table 4 reports the first set of ordered probit regressions, using the current religious affiliation measure. The zero order regression in Panel A shows that the coefficient on CP affiliation is significantly negative. In Panel B, which includes the economic and demographic variables, the coefficient on the $\mathrm{CP}$ variable is smaller - suggesting that the some of the association between CP affiliation and employment status reflects an indirect effect. The signs on the coefficients of the variables added in this panel are in the expected direction: the wife's and husband's education are, respectively, positively and negatively associated with employment; a larger number of children in the household is associated with weaker labor market attachment, and holding the number constant, such attachment is stronger when a child from a former union of the wife or husband is present; a different race/ ethnicity is associated with a higher employment level. Panel C, which adds the two conservative gender ideology variables, shows that each is associated with a lower level of maternal employment. This direct effect accounts for part of the association between CP affiliation and women's work in the labor market, as suggested by the decline in the coefficient on the CP variable from Panel B to Panel C.

The predicted probabilities evaluated at selected values for the explanatory variables provide information on the magnitudes of the associations. In Panel A, the NE probability for a $\mathrm{CP}$ woman is 0.43 ; for her MP counterpart the probability is 0.28 - a gap of 15 percentage points. The gap narrows to 12 percentage points in Panel B, and to 9 percentage points in Panel C. At the same time, the CP- MP gap calculated in terms of the FT employment probability 
shows a decline from 14 percentage points in Panels A and B to 10 percentage points in Panel C. Examination of the results for the economic and demographic variables provides some perspective regarding the size of the CP effect. For example, Panel B shows that the NE probability for a woman married to a high-school dropout is 0.24 , compared to 0.34 for her counterpart married to a college graduate - a gap of 10 percentage points.

The non-trivial size of the CP coefficient in Panel C suggests the importance of other, unmeasured variables. These may include a disadvantage of CP women in terms of access to social networks that are valuable in the labor market (Keister 2008, 2011; Massengill 2008; Sherkat 2010), greater responsibility for household work among CP women (Ellison \& Bartkowski 2002), and differences between CP and non-CP women in dimensions of gender ideologies not measured in our data.

\section{Current Religious Participation}

Table 5, Panel A shows pronounced variations in the level of maternal employment with the extent of religious participation. Women who report attendance at religious services more than once a week have by far the highest NE probability, 0.48 , followed by 0.39 for those who report attendance on a weekly basis. The coefficients on very high and high attendance are both smaller in size in Panel B. Panel C indicates a further drop in the magnitudes of both coefficients and the first loses statistical significance, suggesting that an important part of the association between religious participation and employment operates through the more traditional attitudes held by women who have high or very high attendance at religious services.

A different pattern of associations emerges in connection with zero attendance at religious services: the coefficient is negative and marginally significant in Panel A $(p=0.11)$ and insignificant in Panel B, but relatively large in absolute magnitude and significantly negative in Panel C. If the "benefits from some religious participation effect" takes the form of nonparticipation in religion being conducive to non-participation in the labor force, this could provide an explanation for the observed pattern. The relatively small and marginally significant/ insignificant coefficients in Panels A and B could be interpreted as reflecting this influence effect \#1 for short- cancelling out effect \#2, namely, the tendency for women with zero 
attendance at religious services to have non-traditional attitudes that lead to a higher employment level. Since Panel C controls for the gender ideology variables, the coefficient on the zero attendance variable therein is dominated by effect \#1. Overall, Table 5 suggests the presence of important non-linearities in the association between religious participation and work in the labor market, with an elevated NE probability at both extremes of the religious attendance distribution - at the high end especially.

\section{Current Religious Affiliation and Participation}

The models in Table 6 include variables that combine religious affiliation and participation. The sample sizes for several of the categories are small and the corresponding coefficients cannot be estimated with precision; these results are thus presented as illustrative only. The point estimates in Panel A suggest that, as expected, among women of different religions who have high/ very high religious participation, the NE probability is highest - 0.46 for those affiliated with a CP denomination. That the coefficient on "CP high/ very high" decreases from Panel A to Panels B and C is consistent with the Table 5 analyses which suggested the operation of both direct and indirect influences.

At the other end of the religious participation scale (zero attendance), Panel A shows that there are three other groups with relatively high NE probabilities: lapsed CPs (0.42), lapsed Catholics (0.48), and those within the unaffiliated category who are disconnected from organized religion (0.36). Lapsed MPs are an exception, with a low NE probability, 0.17. The heterogeneity of the unaffiliated category is noteworthy: within this group, it is those who never attend religious services who stand out for their high NE probability.

\section{Reverse Causality}

The discussion above focused on possible pathways by which religious affiliation and participation, and the combination of these two characteristics, may affect women's employment. But our estimates capture causality flowing in the opposite direction also. Mothers of young children who work in the labor market for whatever reason may find themselves adjusting their religious beliefs so as to avoid cognitive dissonance (Zajonc 1960). In the 2006-2010 period covered by our data, many women entered the labor force or increased their involvement in 
market activities in response to unemployment or difficult labor market conditions experienced by their husbands. Such women may have, if needed, revised their religious beliefs and related gender role ideologies accordingly. Other households were affected by the prolonged downturn even more deeply. Among such households, marginalized from society by under-employment or long-term unemployment leading to dropping out of the labor force altogether, recent research suggests that there may have been a tendency to withdraw from institutionalized religion.

Commenting on the growing divergence in well-being between the moderately educated (12-15 years of schooling) and least educated (high school dropouts) on the one hand, and the college educated on the other, Wilcox et al. (2012) suggest that the adversity experienced by low SES groups in recent decades in the areas of marital and labor market outcomes likely stimulated pronounced declines in participation in religious activities. The authors argue that individuals struggling with instability in their family and work lives may be uncomfortable or uninterested in

participating in religious organizations, given the typically traditional character of such organizations. In related work, Schwadel (2008) notes that although teenagers growing up in poverty are especially likely to pray and engage in other forms of personal devotion, they participate less in organized religion than their non-poor counterparts due to various obstacles they face (e.g., transportation barriers, embarrassment about not having the proper clothes). These lines of reasoning suggest that in the 2006-2010 period, non-participation in the labor force may have encouraged some women to join the ranks of the unaffiliated. Overall, the estimates presented in Tables 4, 5 and 6 - and in particular, the association between not participating in the labor force and not participating in religious activities - must be interpreted as reflecting two-way causality.

\section{Childhood and Current Religious Affiliation}

The information in the survey on the religious affiliation in which the respondent was raised helps shed some light on the reciprocal causality concerns raised above. Gender ideologies are often developed early in life (Pearce \& Thornton 2007), suggesting that girls raised in CP denominations would tend to go on to high levels of NE later in the life cycle - as the mothers of young children. Table 7, Panel A shows that women with stable CP affiliations over time have a relatively high NE probability, 0.39 , compared to 0.27 for the reference group -women raised in 
a non-CP denomination who now are MPs. The childhood influence is visible even among those who had made a choice at some point to switch to a non-CP denomination - the NE probability for this group is 0.37 . These effects of childhood CP affiliation - which show a gap in the NE probability between CPs and MPs of 10-12 percentage points - are less contaminated by endogeneity problems than the estimates in the earlier tables. ${ }^{9}$ As expected, the coefficient is substantially larger in absolute magnitude for respondents who had made a choice of converting from a non-CP to a CP denomination, and the NE probability for these women is 0.51 . The CPMP gap in this case is about double, at 24 percentage points. This estimate includes reverse causality: women who are staying home with their young children are more likely than their employed counterparts to switch to a CP denomination. Comparing the probabilities in the first two rows of Table 5 with those in the third provides as a first approximation an estimate of the magnitude of the biases associated with using measures of current affiliation.

\section{DISCUSSION}

CPs have long been over-represented among low SES groups in the U.S. and the single paycheck on which many CP households live has been identified as an important contributing factor to their low accumulation of wealth over the life cycle (Keister 2008). Our analysis of data on non-Hispanic white married women with young children from the 2006-2010 NSFG shows that CPs continue to display low levels of attachment to the labor market: their NE probability is 0.43, compared to 0.28 for MPs. Women who attend religious services more than once a week or once a week also have weak labor market attachment - their NE probabilities are 0.48 and 0.39 , respectively, compared to 0.29 for their counterparts who have moderate or low levels of religious participation. Overall, these results suggest that the aggregate statistics presented by Putnam \& Campbell (2010) - indicating that CP women and highly religious women no longer stand out for markedly lower levels of employment - mask considerable variations across groups that differ by race/ethnicity, marital status, and the presence of young children.

It is noteworthy that at the other end of the religious participation distribution, those with zero attendance at religious services also have a relatively high NE probability - 0.35. It appears that this is a heterogeneous group - with a difference between lapsed Catholics, lapsed CPs and the unaffiliated with zero attendance on one hand, and lapsed MPs on the other. If confirmed by 
future research, this difference deserves more attention, as does the difference between the unaffiliated who have zero vs some attendance at religious services. The pronounced increase in the ranks of the religious nones over the past decades suggests that these issues merit priority in the agenda for future investigations.

Numerous studies have documented a convergence of non-Hispanic Catholics to the MP pattern in socio-economic and demographic behavior (Keister 2007; Lehrer 2009). Various factors have contributed to this convergence, including distance from the immigrant experience and assimilation, attendance at Catholic schools, and instrumental attitudes towards work (Keister 2011). The present findings - showing relatively high levels of employment among Catholic women, comparable to that of their MP counterparts - suggest that convergence in female labor supply behavior has been part of the upward social mobility story of this group. It is important to note that within the U.S., Hispanic Catholics continue to be a disadvantaged segment of society (Keister 2011). Beyond the U.S., international comparisons have found that countries in which Protestantism is the main faith display substantially higher rates of female labor force participation than countries where other religions, including Catholicism, are dominant (Feldman 2007). These findings illustrate that effects associated with religion can vary greatly across contexts (Stark 1996) and they underscore that it is not possible to extrapolate the present results for non-Hispanic Catholics to Catholics of other races/ ethnicities within the U.S. or to Catholics in other countries.

With few exceptions (Fortin 2005; Glass \& Nath 2006), the role of religious and other cultural factors on the male-female wage gap has received surprisingly little attention in the literature. After accounting for the various socio-economic and demographic factors that influence wages, the question is to what extent the unexplained male-female wage gap is due to discrimination in the labor market vs other factors, including male-female differences in the perceived benefits and costs of investments in labor-market specific human capital. We found that among married women with children, those who are affiliated to a CP denomination and those who have high levels of attendance at religious services work less in the labor market. This implies that they are not only making small or zero contributions to household earnings at present - they are also making fewer investments in on-the-job training that enhance future 
wages. These patterns likely hold also for other under-researched theologically conservative religious, including Mormons, orthodox Jews, and Muslims. ${ }^{10}$ Household work is the other side of this coin. Based on data from the 1987-88 NSFH, Ellison \& Bartkowski (2002) found that CP wives devote more time to household tasks than their non-CP counterparts. It would be useful to study whether these patterns continue to hold today, and whether they hold also for women who have other conservative faiths and for highly religious women in general. Women who devote considerable effort to household work have less energy left for labor market activities, and a main pathway through which religious conservatism may affect women's wages is by encouraging the choice of less demanding jobs (Glass \& Nath 2006).

Recent studies have begun to specify religion in a way that allows for the effects of religious participation (high vs low attendance at religious activities) to vary by affiliation (Lehrer 2010; Ellison et al. 2011; Fitzgerald \& Glass 2012). The present findings suggest that an additional refinement is important - the high vs low classification of religious attendance is insufficient, because there are marked non-linearities in the effects associated with religious participation. We found a significant difference between moderate/low and high/very high participation, and at the other end of the distribution, a difference in the opposite direction between moderate/ low and none, i.e., the relationship between religious participation and the NE probability is U-shaped. ${ }^{11}$ If religious participation had been entered as a continuous variable, or as a simple high - low dichotomy, the estimated coefficients would have indicated that religious participation does not matter. An intriguing question for future research - ideally based on rich, longitudinal data sets, with information on both childhood and adult religion - is whether there are similar non-linearities in the associations between religion and each of the other socio-economic and demographic behaviors, including education, wages, union formation and dissolution, fertility, and wealth accumulation. 


\section{ENDNOTES}

${ }^{1}$ Using data from the 1979-2000 National Longitudinal Surveys of Youth, Pearce (2010) found that, along with CPs, Catholic women have a high rate of premarital births. And using data from the 1987-88 and 1992 NSFH, Bartkowski \& Xu (2010) found that Catholics remained committed to an important dimension of traditional gender ideologies - the view that maternal employment is harmful to young children. Both of these studies, however, were based on samples that included Hispanics. As Keister (2011) has noted, although signs of upward mobility have begun to emerge among Hispanic Catholics, at present this group is far from convergence to the MP patterns.

${ }^{2}$ Mechanisms that explain why participation in religious activities may lead to beneficial outcomes include a social capital effect (religion helps integrate people to supportive social networks), a regulative effect (most religions encourage healthy behaviors) and the psychological benefits that some involvement in religion can generate, among others (Sherkat \& Ellison 1999; Waite \& Lehrer 2003; Smith 2003).

${ }^{3}$ Chiswick \& Huang (2008) suggest that the adverse influence of very high religious participation on the earnings of Jewish men may arise from a "crowding out" effect: a very high attendance at religious services may leave less time for secular endeavors; in addition, life-style restrictions of highly observant groups (e.g., where to live and work, occupational choices, work hours) may limit earnings. In the relationship between religious participation and gender-based violence, an adverse effect may be present at very high levels of religious participation because conservative theologies have the potential to be taken to an extreme and misinterpreted to condone violence against women (Nason-Clark 2004; Lehrer et al. 2009).

${ }^{4}$ Following Keister (2008) and other scholars, we use somewhat different terminology in this paper: our "Conservative Protestant” category corresponds to Steensland et al.’s (2000) "Evangelical Protestants.”

${ }^{5}$ The survey also included an item on the current salience of religion in the person's life. Unfortunately this item could not be used, because it was addressed only to respondents who reported affiliation to some religion. The assumption made by NSFH staff that religion is always 
of no importance for the unaffiliated was contradicted by responses to other questions: $31.54 \%$ of the religious nones in our sample reported non-zero attendance at religious services.

${ }^{6}$ The childhood affiliation variable in the 2006-2010 NSFH was coded with the following categories: (1) No religion; (2) Catholic; (3) Methodist, Lutheran, Presbyterian, Episcopalian; (4) Baptist, Southern Baptist; (5) Fundamentalist Protestant; (6) Other Protestant; (7) Protestant- no specific denomination; (8) other; and (9) no response. We combined (1), (2), and (3) into "Non CP,” and (4), (5) and (6) into “CP.” Following Putnam and Campbell (2010, p. 572), cases in category (7) were assigned to the CP group if the respondent was born in 1980 or after, and to the Non-CP group otherwise. Observations with responses in categories (8) and (9) were eliminated, leaving a sample of $\mathrm{N}=765$ cases for these analyses.

${ }^{7}$ For further discussion of these economic and demographic variables in the context of labor supply regressions, see Lehrer (1995, 1999b). A dummy variable for residence in a rural area was included in preliminary regressions and dropped because it was always insignificant. Unfortunately our data do not contain information on region of residence.

${ }^{8}$ Other domains of gender ideology include views as to whether husbands should be expected to do household work, and whether men should have priority in access to jobs when jobs are scarce, among many others (Fortin 2005; Davis \& Greenstein 2009).

${ }^{9}$ Use of religious affiliation measured in childhood does not entirely eliminate endogeneity problems, given the host of unobserved variables that are correlated with it.

${ }^{10}$ For an analysis of the labor supply behavior of Arab-American women, see Read (2010).

${ }^{11}$ These patterns can also be described as an inverse U-shaped relationship between religious participation and the FT employment probability - similar to the shape of the religious participation - earnings relationship for Jewish men found by Chiswick \& Huang (2008). 


\section{REFERENCES}

Bartkowski, J.P. \& Xu, X. ( 2010) "Religion and Family Values Reconsidered: Gender Traditionalism among Conservative Protestants.” Pp. 106-125 in C. G. Ellison and R. A. Hummer (eds.) Religion, Family Life, and Health in the United States. New Brunswick: Rutgers University Press.

Brinkerhoff, M. B. \& MacKie, M. M. (1988), "Religious Sources of Gender Traditionalism,” in The Religion and Family Connection (D. Thomas, ed.), pp. 232-257, Religious Studies Center, Brigham Young University, Salt Lake City.

Chiswick, B.R. \& Huang, J. (2008) "The Earnings of American Jewish Men: Human Capital, Denomination and Religiosity."Journal for the Scientific Study of Religion 47(4): 694709.

Chiswick, C. U. (2006) "An Economic Perspective on Religious Education: Complements and Substitutes in a Human Capital Portfolio.” Research in Labor Economics 24: 449- 467.

----- (2010) “Economics and Religion.”In R. Free (ed.) 21 ${ }^{\text {st }}$ Century Economics: A Reference Handbook, Sage Publications.

Cohen-Zada, D. and Sander, W. (2009) "Religious Participation Versus Shopping: What Makes People Happier?" Unpublished manuscript.

Darnell, A., and Sherkat, D. E. (1997) "The Impact of Protestant Fundamentalism on Educational Attainment.” American Sociological Review 62:306-315.

Davis, S. N. \& Greenstein, T. N. (2009) "Gender Ideology: Components, Predictors, and Consequences.” Annual Review of Sociology 35: 87-105.

Ecklund, E.H. \& Scheitle, C. (2007) Religion among Academic Scientists: Distinctions, Disciplines and Demographics. Social Problems 54: 289-307.

England, P., García-Beaulieu, C. \& Ross, M. (2004). “Women’s Employment among Blacks, Whites, and Three Groups of Latinas: Do More Privileged Women Have Higher Employment?” Gender \& Society 18: 494- 509.

Ellison, C. G. \& Bartkowski, P. J. (2002) "Conservative Protestantism and the Division of Household Labor Among Married Couples.” Journal of Family Issues 23(8): 950-985.

Ellison, C. G. \& Hummer, R. A, eds. (2010) Religion, Family Life, and Health in the United States. New Brunswick: Rutgers University Press. 
Ellison, C. G. \& Sherkat, D. E. (1995) "The 'Semi-involuntary Institution' Revisited: Regional Variations in Church Participation among Black Americans." Social Forces 73(4): 14151437.

Ellison, C. G., Wolfinger, N. H. \& Ramos-Wada, A. I. (2011) “Attitudes Toward Marriage and Cohabitation among Working-Age Latinos: Does Religion Matter?” Presented at the annual meetings of the Population Association of America, Washington, D.C.

Feldman, H. (2007) "Protestantism, Labor Force Participation, and Employment Across Countries.” American Journal of Economics and Sociology 66(4):795-816.

Fitzgerald, S. T. \& Glass, J. (2008) "Can Early Family Formation Explain the Lower Educational Attainment of U.S. Conservative Protestants?" Sociological Spectrum 28: 556-577.

Fitzgerald, S.T. \& Glass, J. (2012) "Conservative Protestants, Early Transitions to Adulthood, and the Intergenerational Transmission of Class.” Pp. 49-74 in L. Keister, J. McCarthy \& R. Finke (eds.) Religion, Work and Inequality. Bingley, United Kingdom: Emerald.

Fortin, N.M. (2005) "Gender Role Attitudes and the Labour Market Outcomes of Women Across OECD Countries.” Oxford Review of Economic Policy 21(3): 416-438.

Gallagher, S.K. \& Smith, C. (1999) "Symbolic Traditionalism and Pragmatic Egalitarianism: Contemporary Evangelicals, Families and Gender.” Gender \& Society 13:211- 233.

Glass, J \& Jacobs, J. (2005) "Childhood Religious Conservatism and Adult Attainment among Black and White Women." Social Forces 84(1): 555-579.

Glass, J. \& Nath, L.E. (2006) "Religious Conservatism and Women's Market Behavior Following Marriage and Childbirth." Journal of Marriage and the Family 68 (August): 611-629.

Gross, N. \& Simmons, S. (2009) "The Religiosity of American College and University Professors.” Sociology of Religion 70:101-129.

Gruber, J. (2005) "Religious Market Structure, Religious Participation, and Outcomes: Is Religion Good for You?” Advances in Economic Analysis and Policy 5(1): article 5. http://www.bepress.com/bejeap/advances/vol5/iss1/art5

----- \& Hungerman, D.M. (2008) "The Church Versus the Mall: What Happens when Religion Faces Increased Secular Competition?" The Quarterly Journal of Economics, May: 831862.

Hout, M. \& Fischer, C. S. (2002) "Why More Americans Have No Religious Preference: Politics and Generations.” American Sociological Review 67(2): 165-190. 
Hout, M., Greeley, A., and Wilde, M. J. (2001) "The Demographic Imperative in Religious Change in the United States." The American Journal of Sociology 107(2): 468-500.

Jones, E. F. \& Westoff, F. C. (1979) “The End of ‘Catholic’ Fertility.” Demography 16(2): 209218.

Keister, L. A. (2003) "Religion and Wealth: The Role of Religious Affiliation and Participation in Early Adult Asset Accumulation.” Social Forces 82: 173-205.

----- (2005) Getting Rich: America's New Rich and How They Got that Way. Cambridge: Cambridge University Press.

----- (2007) “Upward Wealth Mobility: Exploring the Roman Catholic Advantage.” Social Forces 85: 1195-1126.

----- (2008) "Conservative Protestants and Wealth: How Religion Perpetuates Asset Poverty." American Journal of Sociology 113:1237-1271.

----- (2010) "Childhood Religious Denomination and Early Adult Asset Accumulation." Pp.164185 in C. Ellison and R. Hummer (eds.) Religion, Family Life, and Health in the United States. New Brunswick: Rutgers University Press.

----- (2011) Faith and Money: How Religion Contributes to Wealth and Poverty. Cambridge: Cambridge University Press.

Lehrer, E.L. (1992) “The Impact of Children on Married Women’s Labor Supply: Black-White Differentials Revisited.” Journal of Human Resources 27(3): 422-444.

----- (1995) "The Effects of Religion on the Labor Supply of Married Women.” Social Science Research 24: 281-301.

----- (1999a) "Religion as a Determinant of Educational Attainment: An Economic Perspective." Social Science Research 28: 358-379.

----- (1999b) "Married Women’s Labor Supply Behavior in the 1990s: Differences by Life-Cycle Stage.” Social Science Quarterly 80(3): 574-590.

----- (2004) "Religion as a Determinant of Economic and Demographic Behavior in the United States.” Population and Development Review 30(4): 707-726.

----- (2006) "Religion and High School Graduation: A Comparative Analysis of White and Black Young Women.” Review of Economics of the Household 4(3): 277-293.

----- (2009) Religion, Economics, and Demography: The Effects of Religion on Education, Work, and the Family. New York: Routledge Press. 
----- (2010) "Religious Affiliation and Participation as Determinants of Women's Educational Attainment and Wages.” Pp. 186-205 in C. G. Ellison and R. A. Hummer (eds.) Religion, Families and Health in the United States: New Directions in Population Based Research. Rutgers University Press.

----- (2011) "Religion, Human Capital Investments, and the Family in the United States.” Pp. 3956 in R. M. McCleary (ed.) The Oxford Handbook of the Economics of Religion. Oxford: Oxford University Press.

----- \& Chiswick, C. (1993) “Religion as a Determinant of Marital Stability.” Demography 30(3): 385-404.

-----, Lehrer, V. L. \& Krauss, R. (2009) "Religion and Intimate Partner Violence in Chile: Microand Macro-Level Influences." Social Science Research 38(3):635-643.

Massengill, R. P. (2008) "Educational Attainment and Cohort Change among Conservative Protestants, 1972-2004.” Journal for the Scientific Study of Religion 47(4): 545-562.

----- \& MacGregor, C. A. (2012) "Religious Nonaffiliation and Schooling: The Educational Trajectories of Three Types of Religious 'Nones.’” Pp. 183-203 in L. Keister, J. McCarthy \& R. Finke (eds.) Religion, Work and Inequality. Bingley, United Kingdom: Emerald.

Nason-Clark, N. (2004) When Terror Strikes at Home: The Interface between Religion and Domestic Violence. Journal for the Scientific Study of Religion 43(3): 303-10.

Pearce, L. D. (2010) "Religion and the Timing of Births in the United States.” Pp. 19-39 in C. G. Ellison and R. A. Hummer (eds.) Religion, Families and Health in the United States: New Directions in Population Based Research. Rutgers University Press.

----- \& Thornton, A. (2007) "Religious Identity and Family Ideologies in the Transition to Adulthood.” Journal of Marriage and the Family 69:1227-1243.

Putnam, R. D. \& Campbell, D. E. (2010) American Grace: How Religion Divides and Unites Us. New York: Simon \& Schuster.

Read, Ghazal J. (2010) “Religion, Family, and Women’s Employment Among Muslim and Christian Arab Americans.” Pp. 206-228 in C. G. Ellison and R. A. Hummer (eds.) Religion, Families and Health in the United States: New Directions in Population Based Research. Rutgers University Press.

Roof, W.C. (1999) Spiritual Marketplace. Princeton: Princeton University Press. 
Sherkat, D. E. (2000) "That They be Keepers of the Home: The Effect of Conservative Religion on Early and Late Transition into Housewifery.” Review of Religious Research 41(3): 344-358.

----- (2010) "Religion and Verbal Ability." Social Science Research 39: 2-13.

----- (2012) "Religion and the American Occupational Structure.” Pp. 75- 102 in L. Keister, J. McCarthy \& R. Finke (eds.) Religion, Work and Inequality. Bingley, United Kingdom: Emerald.

----- \& Darnell, A. (1999) “The Effects of Parents' Fundamentalism on Children's Educational Attainment: Examining Differences by Gender and Children's Fundamentalism.” Journal of the Scientific Study of Religion 38(1):23-35.

----- \& Ellison, C. (1999) "Recent Developments and Current Controversies in the Sociology of Religion.” Annual Review of Sociology 25: 363-394.

Schwadel, P. (2008) “Poor Teenagers’ Religion.” Sociology of Religion, 69(2): 125-149.

Smith, C. (2003) “Theorizing Religious Effects Among American Adolescents.” Journal for the Scientific Study of Religion 42(1): 17-30.

Stark, R. (1996) "Religion as Context: Hellfire and Delinquency One More Time." Sociology of Religion 56(2): 163-173.

Steensland, B., Park, J. Z., Regnerus, M. D., Robinson, L. D., Wilcox, W. B., and Woodberry, R. D. (2000) "The Measure of American Religion: Toward Improving the State of the Art." Social Forces 79(1): 1-28.

Sweet, J. A. \& Bumpass, L. L. (1990) "Religious Differentials in Marriage Behavior and Attitudes.” NSFH Working Paper No. 15, University of Wisconsin.

Uecker, J. E. \& Stokes, C. E. (2009) "Early Marriage in the United States." Journal of Marriage and the Family 70(4):835-846.

Vella, F. (1994) "Gender Roles and Human Capital Investment: The Relationship between Traditional Attitudes and Female Labour Market Performance.” Economica 61(242): 191-211.

Waite, L. \& Lehrer, E. L. (2003) "The Benefits from Marriage and Religion in the United States: A Comparative Analysis.” Population and Development Review 29(2): 255-275. 
Wilcox, W. B., Cherlin, A. J., Uecker, J. E., \& Messel, M. (2012) “No Money, No Honey, No Church: The Deinstitutionalization of Religious Life Among the White Working Class." Pp. 227-250 in L. Keister, J. McCarthy \& R. Finke (eds.) Religion, Work and Inequality. Bingley, United Kingdom: Emerald.

Zajonc, R. B. (1960)”The Concepts of Balance, Congruity and Dissonance.” Public Opinion Quarterly 24(2): 280-296. 
Table 1. Religion Variables

Mean

PANEL A: Current Religious Affiliation and Participation

Affiliation

Mainline Protestant (MP) - reference

Conservative Protestant (CP)

Catholic (CATH)

No religious affiliation (NOREL)

0.19

Attendance at religious services

Very high (more than once a week)

High (once a week)

Moderate/low (less than once a week) - reference

None

0.20

PANEL B: Current Affiliation and Participation Considered Jointly
MP - very high/high
0.08
MP - moderate/low - reference
MP - none
CP - very high/ high
0.17
CP - moderate / low
0.09
$\mathrm{CP}$ - none
0.02 
Table 1. Religion Variables (continued)

\begin{tabular}{lc}
\hline & Mean \\
\hline CATH - very high/ high & 0.08 \\
CATH - moderate/ low & 0.17 \\
CATH - none & 0.02 \\
NOREL - some & 0.06 \\
NOREL - none & 0.13 \\
& \\
PANEL C: Childhood and Current Affiliation Considered Jointly & \\
CP - CP & 0.21 \\
CP - non CP & 0.10 \\
Non CP - CP & 0.07 \\
Non CP - MP - reference & $(0.21)$ \\
Non CP - CATH & 0.26 \\
Non CP - NOREL & 0.15 \\
\hline
\end{tabular}

N = 783 for Panels A and B; N = 765 for Panel C. 
Table 2. Economic and Demographic Variables

\begin{tabular}{|c|c|c|}
\hline & Definition & Mean \\
\hline Wife's age & Respondent's (R) age at date of interview & 32.37 \\
\hline Wife's education & $\begin{array}{l}=1 \text { if schooling completed by } \mathrm{R} \text { as of survey } \\
\text { date is in category indicated }\end{array}$ & \\
\hline Less than high school degree & & 0.12 \\
\hline 12-15 (reference) & & 0.45 \\
\hline College degree & & 0.29 \\
\hline Graduate or professional degree & & 0.14 \\
\hline Husband's education & $\begin{array}{l}=1 \text { if schooling completed by R's husband's as } \\
\text { of survey date is in category indicated }\end{array}$ & \\
\hline Less than high school degree & & 0.08 \\
\hline 12-15 (reference) & & 0.52 \\
\hline College degree & & 0.26 \\
\hline Graduate or professional degree & & 0.13 \\
\hline Number of children & number of children currently in household & 2.07 \\
\hline Child - wife & $\begin{array}{l}=1 \text { if child from a previous union of } \mathrm{R} \text { is present } \\
\text { in household }\end{array}$ & 0.11 \\
\hline Child - husband & $\begin{array}{l}=1 \text { if child from a previous union of R's } \\
\text { husband is present in household }\end{array}$ & 0.04 \\
\hline Different race/ethnicity & $\begin{array}{l}=1 \text { if race/ethnicity of R's husband is other than } \\
\text { non-Hispanic white }\end{array}$ & 0.10 \\
\hline
\end{tabular}

$\mathrm{N}=783$ 
Table 3. Means of Conservative Gender Ideology Variables by Religious Affiliation and Participation ${ }^{\text {a }}$

\begin{tabular}{|c|c|c|c|c|c|c|c|}
\hline & \multicolumn{4}{|c|}{ Panel A: Affiliation ${ }^{\mathrm{b}}$} & \multicolumn{3}{|c|}{ Panel B: Frequency of attendance ${ }^{c}$} \\
\hline & MP & $\mathrm{CP}$ & CATH & NOREL & Very high/high & Moderate/low & None \\
\hline Separate spheres & 2.32 & $3.01 * *$ & 2.18 & $1.98 * *$ & $2.75 * *$ & 2.31 & $2.09 *$ \\
\hline Relationship quality & 1.73 & $1.97 * *$ & 1.73 & 1.71 & 1.87 & 1.79 & 1.69 \\
\hline
\end{tabular}

$\mathrm{N}=783$

$* * p<.05, * p<.10$

a Both variables range from 1 to 5 , with a higher value indicating more conservative ideology. The mean of the separate spheres variable is 2.41 , and the standard deviation is 1.25 ; the respective figures for the relationship quality variable are 1.79 and 0.90 .

b Statistical tests correspond to comparisons to the MP category. Pairwise comparisons revealed the following additional statistically significant differences: CP vs. CATH $(p<.05)$, CP vs. NOREL $(p<.05)$ for both gender ideology variables and CATH vs. NOREL $(p<.10)$ for the separate spheres variable.

c Statistical tests correspond to comparisons to the moderate/low attendance category. Pairwise comparisons revealed the following additional statistically significant differences: very high/high attendance vs. none $(p<.05)$ for both gender ideology variables. 
Table 4. Employment Status and Current Religious Affiliation ${ }^{a}$

\begin{tabular}{|c|c|c|c|c|c|c|c|c|c|c|c|c|}
\hline & \multicolumn{4}{|c|}{ Panel A: Zero order } & \multicolumn{4}{|c|}{$\begin{array}{l}\text { Panel B: Adding economic and } \\
\text { demographic variables }\end{array}$} & \multicolumn{4}{|c|}{$\begin{array}{l}\text { Panel C: Adding gender } \\
\text { ideology variables }\end{array}$} \\
\hline & Coefficient & FT & $P T$ & $N E$ & Coefficient & FT & $P T$ & $N E$ & Coefficient & $F T$ & $P T$ & $N E$ \\
\hline \multicolumn{13}{|l|}{ Affiliation } \\
\hline MP (reference) & -- & 0.44 & 0.27 & 0.28 & -- & 0.47 & 0.29 & 0.25 & -- & 0.46 & 0.30 & 0.24 \\
\hline $\mathrm{CP}$ & $-0.40(0.11)^{* *}$ & 0.30 & 0.28 & 0.43 & $-0.36(0.12)^{* *}$ & 0.33 & 0.30 & 0.37 & $-0.25(0.12)^{* *}$ & 0.36 & 0.31 & 0.33 \\
\hline CATH & $-0.08(0.11)$ & 0.42 & 0.28 & 0.31 & $-0.08(0.12)$ & 0.43 & 0.29 & 0.27 & $-0.10(0.12)$ & 0.42 & 0.30 & 0.28 \\
\hline \multicolumn{13}{|l|}{ Economic/demographic variables } \\
\hline Less than high school degree & & & & & $-0.65(0.15)^{* *}$ & 0.23 & 0.28 & 0.49 & $-0.68(0.15)^{* *}$ & 0.22 & 0.29 & 0.49 \\
\hline College degree & & & & & $0.08(0.11)$ & 0.50 & 0.28 & 0.23 & $0.02(0.11)$ & 0.46 & 0.30 & 0.24 \\
\hline Graduate or professional degree & & & & & $0.35(0.15)^{* *}$ & 0.60 & 0.24 & 0.15 & $0.24(0.15)^{* *}$ & 0.55 & 0.27 & 0.18 \\
\hline Wife's age & & & & & $0.10(0.07)$ & & & & $0.08(0.07)$ & & & \\
\hline 26 & & & & & & 0.41 & 0.29 & 0.30 & & 0.40 & 0.31 & 0.29 \\
\hline 38 & & & & & & 0.49 & 0.28 & 0.23 & & 0.49 & 0.29 & 0.22 \\
\hline Wife’s age-squared/100 & & & & & $-0.13(0.11)$ & & & & $-0.10(0.11)$ & & & \\
\hline Number of children in household & & & & & $-0.22(0.05)^{* *}$ & & & & $-0.21(0.05)^{* *}$ & & & \\
\hline 1 child & & & & & & 0.55 & 0.26 & 0.18 & & 0.54 & 0.27 & 0.18 \\
\hline 3 children & & & & & & 0.38 & 0.30 & 0.32 & & 0.38 & 0.31 & 0.31 \\
\hline
\end{tabular}


Table 4 (Continued)

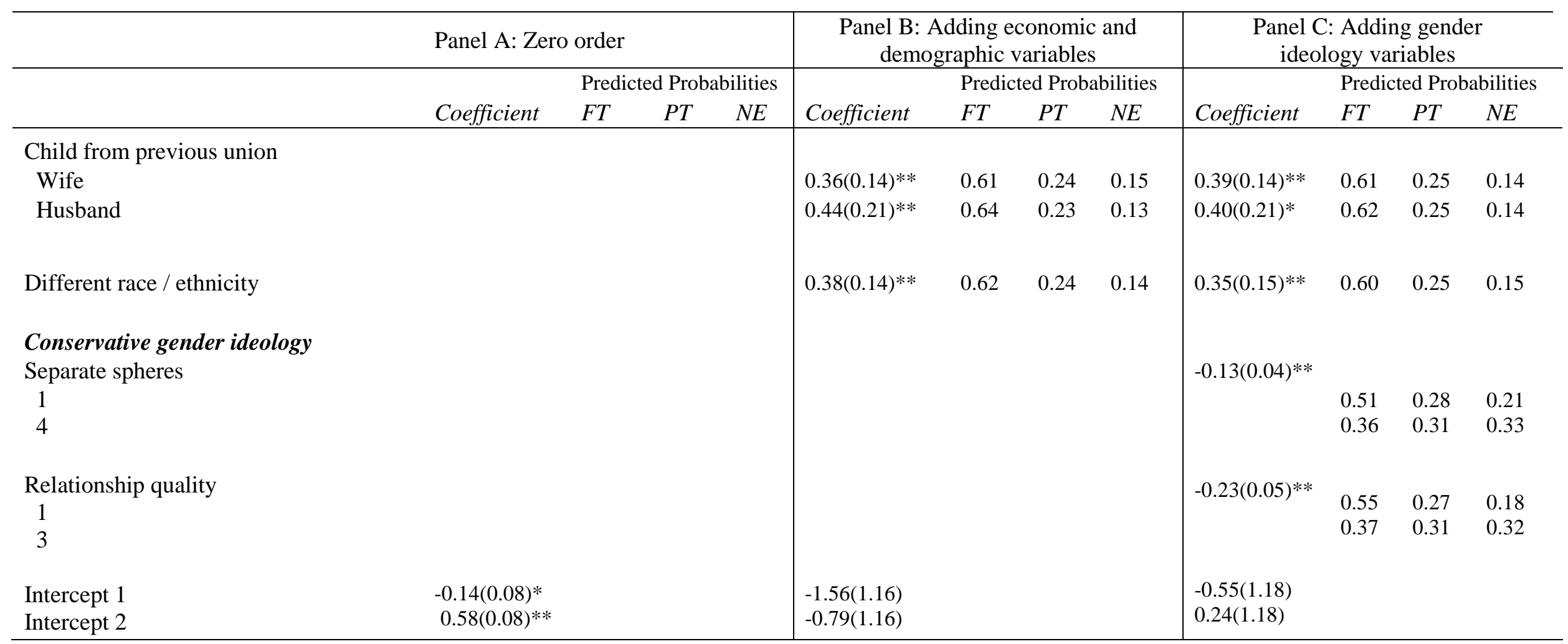

$\mathrm{N}=783$

$* * p<.05, * p<.10$

${ }^{a}$ The reference person in all panels is affiliated to a MP denomination. In Panels B and C her economic/ demographic characteristics are set at the typical values - the dummy variables are set at the mode and the continuous variables at the mean (two children, age=32); the separate spheres and relationship quality variables in Panel C are also set at the mean (score $=2$ ). The other predicted probabilities correspond to respondents who differ from the reference person in only one trait, as noted in the stub. 
Table 5. Employment Status and Current Religious Participation ${ }^{\mathrm{a}}$

\begin{tabular}{|c|c|c|c|c|c|c|c|c|c|c|c|c|}
\hline & \multicolumn{4}{|c|}{ Panel A: Zero order } & \multicolumn{4}{|c|}{$\begin{array}{l}\text { Panel B: Adding economic and } \\
\text { demographic variables }\end{array}$} & \multicolumn{4}{|c|}{ Panel C: Adding gender ideology variables } \\
\hline & \multirow[b]{2}{*}{ Coefficient } & \multicolumn{3}{|c|}{ Predicted Probabilities } & \multirow[b]{2}{*}{ Coefficient } & \multicolumn{3}{|c|}{ Predicted Probabilities } & \multirow[b]{2}{*}{ Coefficient } & \multicolumn{3}{|c|}{ Predicted Probabilities } \\
\hline & & $F T$ & $P T$ & $N E$ & & $F T$ & $P T$ & $N E$ & & $F T$ & $P T$ & $N E$ \\
\hline \multicolumn{13}{|l|}{ Participation } \\
\hline Very high & $-0.51(0.15)^{* *}$ & 0.25 & 0.27 & 0.48 & $-0.37(0.15)^{* *}$ & 0.31 & 0.30 & 0.40 & $-0.25(0.16)$ & 0.35 & 0.31 & 0.34 \\
\hline High & $-0.29(0.10)^{* *}$ & 0.33 & 0.28 & 0.39 & $-0.23(0.10)^{* *}$ & 0.36 & 0.30 & 0.34 & $-0.18(0.11)^{*}$ & 0.37 & 0.31 & 0.32 \\
\hline Moderate/low (reference) & -- & 0.44 & 0.28 & 0.29 & -- & 0.45 & 0.29 & 0.26 & -- & 0.44 & 0.30 & 0.26 \\
\hline None & $-0.17(0.11)$ & 0.37 & 0.28 & 0.35 & $-0.13(0.11)$ & 0.39 & 0.30 & 0.31 & $-0.20(0.11)^{*}$ & 0.37 & 0.31 & 0.32 \\
\hline
\end{tabular}

$\mathrm{N}=783$

$* * p<.05, * p<.10$

${ }^{\mathrm{a}}$ The intercepts and coefficients on the economic/demographic and gender ideology variables are not reported for brevity. 
Table 6. Employment Status and Current Religious Affiliation/ Participation ${ }^{\mathrm{a}}$

\begin{tabular}{|c|c|c|c|c|c|c|c|c|c|c|c|c|}
\hline & \multicolumn{4}{|c|}{ Panel A: Zero order } & \multicolumn{4}{|c|}{$\begin{array}{l}\text { Panel B: Adding economic and } \\
\text { demographic variables }\end{array}$} & \multicolumn{4}{|c|}{ Panel C: Adding gender ideology variables } \\
\hline & \multicolumn{4}{|c|}{ Predicted Probabilities } & \multicolumn{4}{|c|}{ Predicted Probabilities } & \multirow[b]{2}{*}{ Coefficient } & \multicolumn{3}{|c|}{ Predicted Probabilities } \\
\hline & Coefficient & $F T$ & $P T$ & $N E$ & Coefficient & $F T$ & $P T$ & $N E$ & & $F T$ & $P T$ & $N E$ \\
\hline \multicolumn{13}{|l|}{ Affiliation and participation } \\
\hline MP very high/high & $-0.37(0.18)^{* *}$ & 0.33 & 0.28 & 0.38 & $-0.32(0.18)^{*}$ & 0.36 & 0.30 & 0.34 & $-0.33(0.18)^{*}$ & 0.36 & 0.31 & 0.33 \\
\hline MP moderate/low (reference) & -- & 0.48 & 0.27 & 0.25 & -- & 0.49 & 0.28 & 0.23 & -- & 0.48 & 0.29 & 0.22 \\
\hline MP none & $0.29(0.27)$ & 0.59 & 0.24 & 0.17 & $0.38(0.27)$ & 0.64 & 0.23 & 0.13 & $0.36(0.28)$ & 0.63 & 0.24 & 0.13 \\
\hline CP very high/high & $-0.57(0.15)^{* *}$ & 0.27 & 0.28 & 0.46 & $-0.45(0.15)^{* *}$ & 0.32 & 0.30 & 0.39 & $-0.31(0.16)^{* *}$ & 0.36 & 0.31 & 0.33 \\
\hline CP moderate/low & $-0.35(0.17)^{* *}$ & 0.34 & 0.28 & 0.37 & $-0.34(0.18)^{*}$ & 0.36 & 0.30 & 0.34 & $-0.27(0.18)$ & 0.38 & 0.31 & 0.31 \\
\hline CP none & $-0.48(0.31)$ & 0.30 & 0.28 & 0.42 & $-0.48(0.32)$ & 0.30 & 0.30 & 0.40 & $-0.54(0.32)^{*}$ & 0.28 & 0.31 & 0.41 \\
\hline CATH very high/high & $-0.29(0.18)$ & 0.37 & 0.28 & 0.35 & $-0.20(0.18)$ & 0.41 & 0.30 & 0.29 & $-0.21(0.19)$ & 0.40 & 0.31 & 0.29 \\
\hline CATH moderate/low & $-0.05(0.15)$ & 0.46 & 0.27 & 0.26 & $-0.07(0.15)$ & 0.46 & 0.29 & 0.25 & $-0.10(0.15)$ & 0.45 & 0.30 & 0.25 \\
\hline CATH none & $-0.62(0.30)^{* *}$ & 0.25 & 0.27 & 0.48 & $-0.47(0.31)$ & 0.31 & 0.30 & 0.39 & $-0.52(0.31)^{*}$ & 0.29 & 0.31 & 0.40 \\
\hline NOREL some & $-0.12(0.19)$ & 0.43 & 0.28 & 0.29 & $-0.05(0.20)$ & 0.47 & 0.29 & 0.24 & $-0.07(0.20)$ & 0.46 & 0.30 & 0.24 \\
\hline NOREL none & $-0.31(0.16)^{* *}$ & 0.36 & 0.28 & 0.36 & $-0.30(0.16)^{*}$ & 0.37 & 0.30 & 0.33 & $-0.37(0.16)^{* *}$ & 0.34 & 0.31 & 0.35 \\
\hline
\end{tabular}

$\mathrm{N}=783$

$* * p<.05, * p<.10$

${ }^{\mathrm{a}}$ The intercepts and coefficients on the economic/demographic and gender ideology variables are not reported for brevity.

We re-estimated the models additional times, changing the reference category. The following difference was significant for Panel A:

CATH moderate/low vs. CATH none $(p<.05)$. 
Table 7. Employment Status and Childhood/Current CP Affiliation ${ }^{\mathrm{a}}$

\begin{tabular}{|c|c|c|c|c|c|c|c|c|c|c|c|c|}
\hline & \multicolumn{4}{|c|}{ Panel A: Zero order } & \multicolumn{4}{|c|}{$\begin{array}{l}\text { Panel B: Adding economic and } \\
\text { demographic variables }\end{array}$} & \multicolumn{4}{|c|}{ Panel C: Adding gender ideology variables } \\
\hline & \multirow[b]{2}{*}{ Coefficient } & \multicolumn{3}{|c|}{ Predicted Probabilities } & \multirow[b]{2}{*}{ Coefficient } & \multicolumn{3}{|c|}{ Predicted Probabilities } & \multirow[b]{2}{*}{ Coefficient } & \multicolumn{3}{|c|}{ Predicted Probabilities } \\
\hline & & $F T$ & $P T$ & $N E$ & & FT & $P T$ & $N E$ & & FT & $P T$ & $N E$ \\
\hline \multicolumn{13}{|c|}{ Childhood/Current CP Affiliation } \\
\hline $\mathrm{CP}-\mathrm{CP}$ & $-0.32(0.13)^{* *}$ & 0.33 & 0.28 & 0.39 & $-0.26(0.13)^{*}$ & 0.36 & 0.30 & 0.33 & $-0.16(0.14)$ & 0.40 & 0.31 & 0.29 \\
\hline CP - Non CP & $-0.28(0.16)^{*}$ & 0.34 & 0.28 & 0.37 & $-0.20(0.16)$ & 0.39 & 0.30 & 0.31 & $-0.17(0.16)$ & 0.39 & 0.31 & 0.30 \\
\hline Non CP - CP & $-0.64(0.18)^{* *}$ & 0.22 & 0.26 & 0.51 & $-0.60(0.18)^{* *}$ & 0.25 & 0.29 & 0.47 & $-0.47(0.19)^{* *}$ & 0.28 & 0.31 & 0.41 \\
\hline Non CP - MP (reference) & -- & 0.45 & 0.28 & 0.27 & -- & 0.46 & 0.29 & 0.25 & -- & 0.46 & 0.30 & 0.24 \\
\hline Non CP - CATH & $-0.07(0.12)$ & 0.42 & 0.28 & 0.30 & $-0.06(0.12)$ & 0.44 & 0.29 & 0.27 & $-0.09(0.12)$ & 0.42 & 0.31 & 0.27 \\
\hline Non CP - NOREL & $-0.05(0.14)$ & 0.43 & 0.28 & 0.29 & $-0.05(0.14)$ & 0.44 & 0.29 & 0.26 & $-0.11(0.15)$ & 0.41 & 0.31 & 0.28 \\
\hline
\end{tabular}

$\mathrm{N}=765$

${ }^{* *} p<.05,{ }^{*} p<.10$

${ }^{\mathrm{a}}$ The intercepts and coefficients on the economic/demographic and gender ideology variables are not reported for brevity. 